\title{
PESTISIDA PADA BUDIDAYA KEDELAI DI KABUPATEN BANTUL D. I. YOGYAKARTA
}

\author{
Arif Anshori $^{1)}$, Catur Prasetiyono ${ }^{1)}$ \\ ${ }^{1)}$ Balai Pengkajian Teknologi Pertanian (BPTP) Yogyakarta \\ email : arifanshori@yahoo.com
}

\begin{abstract}
Soybean farming carried out by farmer in Bantul Regency D.I. Yogyakarta. Pesticides still important in securing the soybean production of plant pests. Some farmers in the extreme assumes that pesticide with dose and high frequency can improve yields. The research was conducted in Bambanglipuro and Srandakan Bantul D.I. Yogyakarta on April to October 2012. The research aims to identify the use of pesticides in farming soybeans, soybean production and farmers income as well as pesticide residues in soybean dry seeds. Interviews were conducted with farmers, include the use of pesticides, soybean production and farmers income. Aside from interviews with farmers, pesticide usage data is also derived from used packaging were found at the site. Soybean dry seeds were taken from the site of the most intensive in the cultivation of soybeans and analyzed pesticide residues. The results showed that soybean farmers use pesticides in farming. Pesticides are used insecticides (69.6\%), fungicides (17.4\%), herbicides (8.7\%) and other types (4.3\%). Soybean yield $1,850 \mathrm{~kg} / \mathrm{ha}$, revenue $\mathrm{Rp}$. 2.932.500,-/ha with $\mathrm{B} / \mathrm{C}$ ratio 1.36 . The active ingredient of pesticide residue organoposfat contained in the soybean dry seeds with concentration $0-0.068 \mathrm{mg} / \mathrm{kg}$.
\end{abstract}

Kata kunci : Bantul, pesticide, soybean

\section{PENDAHULUAN}

Salah satu kendala utama dalam peningkatan produksi kedelai adalah gangguan hama dan penyakit. Hama dan penyakit tanaman kedelai beragam, mulai dari masa penanaman sampai panen. Hama-hama tanaman kedelai di antaranya lalat kacang, lalat batang, dan lalat pucuk, pemakan daun, penggerek polong, pengisap polong. Penyakit yang sering menyerang tanaman kedelai adalah penyakit karat, antraknose, rebah kecambah, busuk daun dan polong, hawar batang, bercak daun serta serangan virus mosaik. Ledakan populasi hama atau penyakit dapat menyebabkan penurunan hasil panen, gagal panen serta kerugian besar di lokasi pertanaman kedelai.

Pestisida sering kali menjadi andalan para petani dalam usaha mengamankan usaha tani kedelai dari hama maupun penyakit. Pestisida mempunyai beberapa kelebihan sehingga sering dimanfaatkan oleh petani, yaitu mudah diperoleh, cara aplikasi mudah serta hasil cepat tampak. Penggunaan pestisida terkesan sudah menyatu dengan para petani kedelai dan bahkan sering kali menjadi senjata pamungkas dalam budidaya kedelai.

Pestisida mempunyai kekurangan berupa dampak buruk bagi kesehatan dan lingkungan.
Residu pestisida bersifat karsinogenik (menyebabkan penyakit kanker) dan secara umum berdampak buruk bagi kesehatan. Residu pestisida dapat tertinggal dalam tanah dan air, menimbulkan resistensi hama dan penyakit serta musuh alami punah. Residu pestisida berdampak buruk bagi produk, manusia, dan lingkungan.

Penggunaan pestisida tidak sepenuhnya mengenai sasaran sehingga menimbulkan residu dan berdampak negatif bagi tanah, air, tanaman maupun manusia. Perilaku petani yang kurang disiplin dalam penggunaan, baik dari segi jenis, takaran maupun frekuensi, dapat menyebabkan tingginya pencemaran.

Penggunaan pestisida menjadi bagian dalam sistem usaha tani kedelai di Kab. Bantul D.I. Yogyakarta. Berbagai cara penggunaan dilakukan oleh petani, ada yang melakukan penyemprotan sesuai anjuran, dosis tinggi bahkan sampai pada pengoplosan pestisida. Penelitian ini bertujuan mengidentifikasi pemakaian pestisida pada usaha tani kedelai di Kab. Bantul D.I. Yogyakarta, produksi dan pendapatan petani kedelai serta residu pestisida pada biji kering kedelai.

\section{METODE PENELITIAN}

Penelitian dilaksanakan pada bulan April sampai Oktober tahun 2012 di Kec. 
Bambanglipuro dan Srandakan Kab. Bantul. Lokasi merupakan kawasan pertanaman kedelai intensif. Wawancara dilakukan terhadap petani kunci, mencakup penggunaan pestisida, produksi dan pendapatan yang diperoleh petani. Selain dari wawancara dengan petani, pendataan pemakaian pestisida juga berasal dari bekas kemasan pestisida di lokasi penelitian.

Contoh biji kering kedelai diambil dari lokasi penanaman kedelai intensif dan dikomposit. Contoh biji kering kedelai dianalisis untuk menentukan kandungan residu pestisida. Analisis dilakukan di Laboratorium Balai Penelitian Lingkungan Pertanian. Ekstraksi dilakukan dengan memanfaatkan pelarut aseton dan n-hexane (Komisi pestisida, 1997) dan diukur dengan Gas Chromatography (GC) 2014 Shimadzu (Shimadzu, 2004).

\section{HASIL DAN PEMBAHASAN}

\section{Produksi, Penerimaan dan Pendapatan Petani}

Petani kedelai di Kec. Bambanglipuro dan Srandakan Kab. Bantul, sudah sering dan secara terus-menerus menanam kedelai. Biaya produksi bukan kendala bagi petani kedelai, namun ketersediaan benih seringkali menjadi faktor pembatas dalam budidaya kedelai. Produksi kedelai dapat menurun drastis apabila pemakaian pestisida ditiadakan. Pemakaian pestisida sering kali efektif menjaga produksi kedelai saat terjadi serangan organisme pengganggu tanaman. Petani tidak keberatan untuk beralih dari pestisida kimia ke hayati, namun demikian ketersediaan pestisida hayati seringkali menjadi kendala. Petani mengalami kesulitan dalam meramu atau mencari pasokan pestisida hayati.

Komponen biaya untuk pestisida hanya sebagian kecil dalam usaha tani kedelai. Namun demikian, dampak aplikasi pestisida terhadap produksi kedelai dan pendapatan sangat besar. Hal ini mendorong petani menjadikan pestisida sebagai senjata andalan dalam usaha tani kedelai. Untuk lebih jelas, produksi, penerimaan dan keuntungan, serta porsi biaya pestisida dalam usaha tani kedelai di Kab. Bantul tahun 2012 dapat dilihat pada Tabel 1.

Biaya produksi pada usaha tani kedelai di Kab. Bantul per hektar mencapai Rp. 8.167.500,-. Biaya ini meliputi biaya alat, sarana produksi dan tenaga kerja. Dengan harga jual kedelai sekitar Rp. 6.000,- / kg, penerimaan petani mencapai Rp. 11.100.000,dengan pendapatan Rp. 2.932.500,- per hektarnya. $\mathrm{B} / \mathrm{C}$ rasio 1,36.

Biaya pembelian pestisida dan penyemprotan Rp. 1.300.000,- meliputi 15,9\% dari total biaya (dengan asumsi penyemprotan menggunakan tenaga kerja di luar rumah tangga tani). Menurut petani kedelai, tanpa pengeluaran $15,9 \%$ untuk biaya pemakaian pestisida, bila terjadi serangan organisme pengganggu tanaman, produksi dapat turun lebih dari $60 \%$ atau bahkan mengalami gagal panen, sehingga merugikan petani. Pada kondisi yang seperti ini, petani kedelai masih memilih memakai pestisida. 
Tabel 1. Produksi, penerimaan dan keuntungan usaha tani kedelai di Kab. Bantul D.I. Yogyakarta tahun 2012

\begin{tabular}{|c|c|c|c|}
\hline URAIAN & Volume & Harga (Rp) & Total ( Rp ) \\
\hline Produksi / Penerimaan & 1.850 & 6.000 & 11.100 .000 \\
\hline \multicolumn{4}{|l|}{ 1. Biaya Alat } \\
\hline a. Sabit (Buah) & 5 & 27.500 & 137.500 \\
\hline b. Karung (Buah) & 40 & 4.500 & 180.000 \\
\hline c. Terpal Penjemur (Buah) & 1 & 250.000 & 250.000 \\
\hline d. Cangkul (Buah) & 1 & 50.000 & 50.000 \\
\hline e. Sewa Handsprayer (Paket) & 1 & 100.000 & 100.000 \\
\hline Total Biaya Alat (1) & & & 717.500 \\
\hline \multicolumn{4}{|l|}{ 2. Biaya Sarana Produksi } \\
\hline a. Benih $(\mathrm{kg} / \mathrm{ha})$ & 40 & 10.000 & 400.000 \\
\hline b. Ponska (kg/ha ) & 200 & 2.600 & 520.000 \\
\hline c. Pupuk Kandang (kg/ha ) & 2.000 & 500 & 1.000 .000 \\
\hline d. Pestisida (Paket/ha ) & 1 & 400.000 & 400.000 \\
\hline e. Pupuk Daun (Botol/ha) & 2 & 90.000 & 180.000 \\
\hline Total Biaya Sarana Produksi (2) & & & 2.500 .000 \\
\hline \multicolumn{4}{|l|}{ 3. Tenaga Kerja } \\
\hline a. Penanaman (HOK) & 20 & 30.000 & 600.000 \\
\hline b. Penyiangan (HOK ) & 70 & 30.000 & 2.100 .000 \\
\hline c. Pemupukan (HOK ) & 20 & 30.000 & 600.000 \\
\hline d. Penyemprotan (HOK ) & 30 & 30.000 & 900.000 \\
\hline $\begin{array}{l}\text { e. Pemanenan (HOK ) } \\
\text { f. Pengeringan/Penjemuran/ }\end{array}$ & 10 & 30.000 & 300.000 \\
\hline Pengepakan (HOK ) & 15 & 30.000 & 450.000 \\
\hline Total Biaya Tenaga Kerja (3) & & & 4.750 .000 \\
\hline Total Biaya $=1+2+3$ & & & 8.167 .500 \\
\hline Pendapatan = Penerimaan - Total Biaya & & & 2.932 .500 \\
\hline B/C Ratio & & & 1,36 \\
\hline
\end{tabular}

\section{Aplikasi Pestisida}

Dalam melaksanakan kegiatan usaha tani kedelai, petani di Kab. Bantul masih memanfaatkan pestisida dalam mengendalikan organisme pengganggu tanaman. Berdasarkan jenis pestisida yang biasa digunakan oleh petani kedelai di Kab. Bantul, dapat dibedakan atas insektisida, fungisida, dan herbisida. Insektisida ditemukan sebanyak 69,6\%, fungisida $17,4 \%$, herbisida $8,7 \%$ dan jenis pestisida lain sebanyak 4,3\% (Gambar 1). 


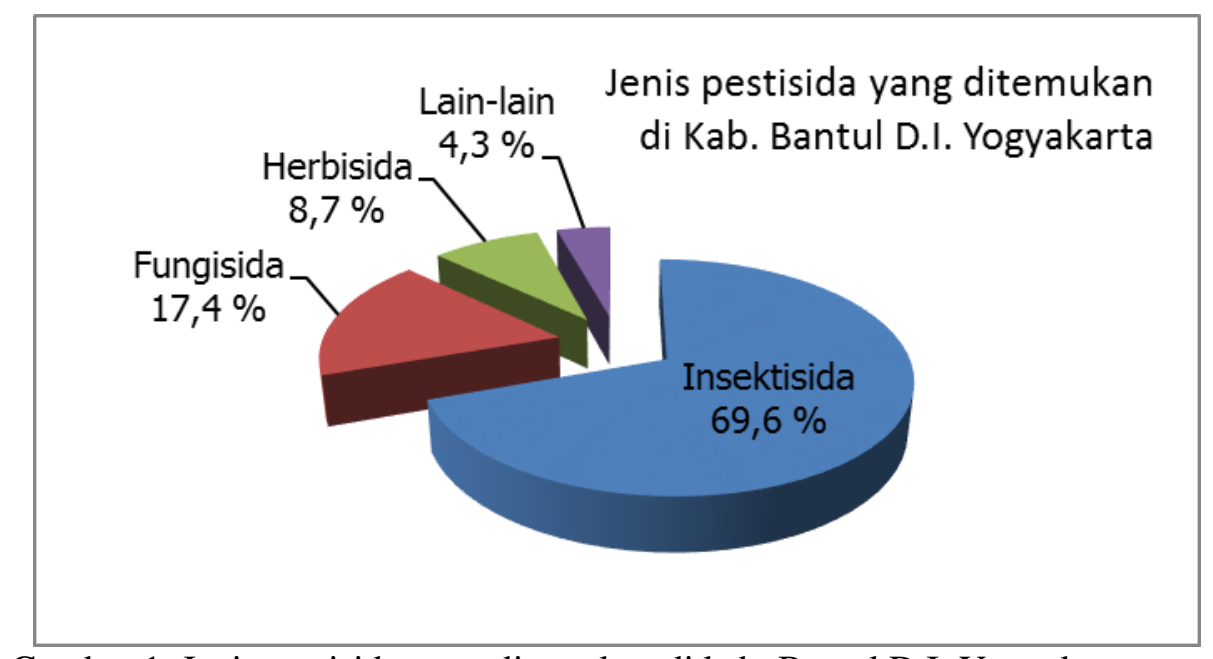

Gambar 1. Jenis pestisida yang ditemukan di kab. Bantul D.I. Yogyakarta.

Petani tidak mematok jenis pestisida yang digunakan, karena pengetahuan tentang pestisida terbatas. Petani kadangkala menggunakan pestisida tidak sesuai anjuran, seperti tidak tepat jenis, dosis, maupun frekuensi. Apabila dirasa perlu, misal karena serangan organisme pengganggu tanaman yang dirasa berat dan berbahaya, petani kadang melakukan pengoplosan pestisida. Petani melakukan tindakan ini semata karena keinginan untuk memperoleh hasil tinggi dan meminimalisasi kegagalan panen. Pertimbangan keselamatan, keamanan, dan dampak terhadap lingkungan seringkali tidak diutamakan.

\section{Residu pestisida}

Beberapa golongan pestisida yang beredar dan sering digunakan oleh petani di antaranya adalah organoposfat, karbamat, piretroit, azole, avermectin dan golongan yang lain. Pestisida golongan organoklorin saat ini sudah dilarang beredar di pasaran, karena bersifat sangat toksik dan mempunyai tingkat persistensi (daya tahan terhadap proses degradasi) sangat tinggi mencapai 30 tahun. Pestisida golongan organofosfat, piretroit dan karbamat bersifat lebih mudah terdegradasi dan tingkat persistensi lebih rendah. Pestisida golongan ini yang saat ini banyak beredar di pasaran.

Tujuan pemakaian pestisida adalah untuk mengendalikan dan melindungi tanaman kedelai dari serangan organisme pengganggu tanaman. Sebagian petani menganggap pemakaian pestisida merupakan tindakan wajib bagi keberhasilan usaha tani kedelai. Dampak negatif pestisida sering kali tidak diperhitungkan, baik terhadap diri sendiri, tanah, air, produk dan maupun lingkungan sekitar. Aplikasi pestisida tidak semua tepat sasaran.

Beberapa bahan aktif golongan organoposfat, ditemukan pada biji kering kedelai dari Kab. Bantul D.I. Yogyakarta. Residu pestisida organoposfat ditemukan dengan bahan aktif diazinon, malation dan profenofos pada berbagai konsentrasi. Sementara itu untuk bahan aktif fenitrotion, paration, metidation, dan klorpirifos tidak ditemukan pada biji kering kedelai (gambar 2). 


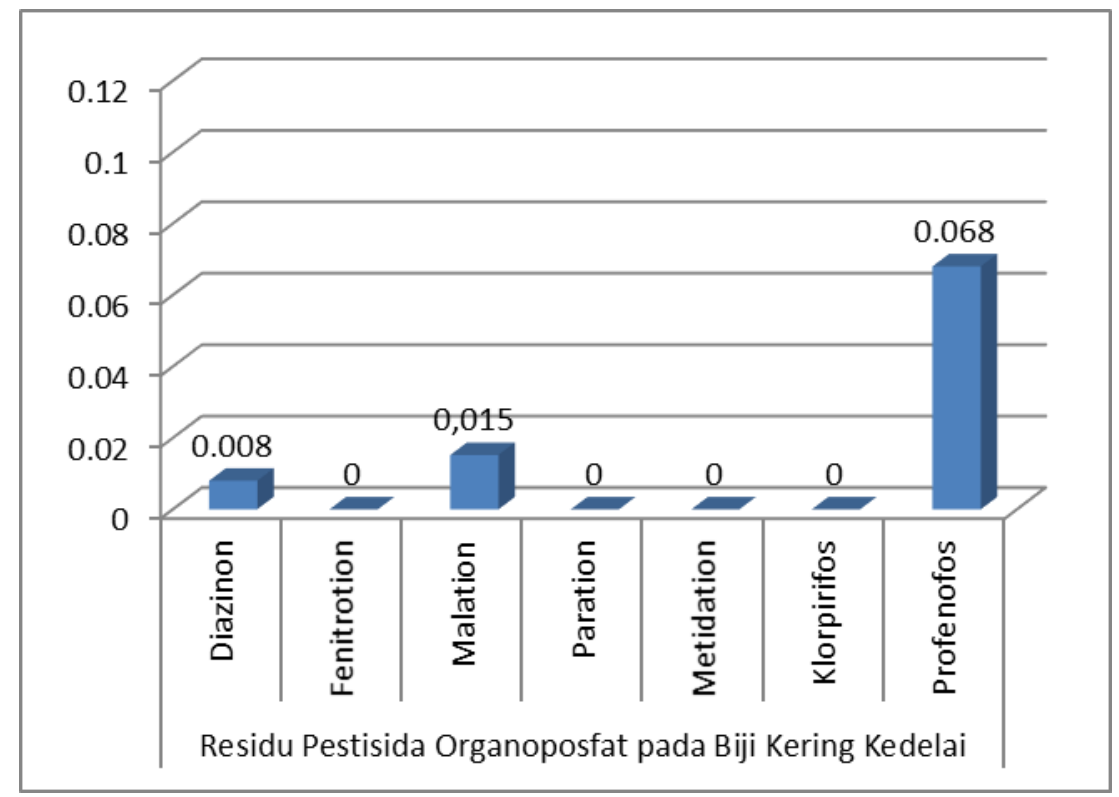

Gambar 2. Residu organoposfat (mg/kg) pada biji kering kedelai di Kab. Bantul D.I. Yogyakarta.

Pestisida dari golongan lain seperti karbamat, azole, avermectin dan beberapa golongan lain juga dipakai oleh petani. Pestisida ini juga akan berpotensi meninggalkan residu pada lahan maupun produk pertanian. Diperlukan adanya identifikasi agar dampak buruk residu pestisida dapat ditanggulangi atau diminimalkan.

\section{Batas Maksimum Residu (BMR) Bahan Aktif Pestisida}

Residu pestisida dalam bahan pangan menentukan mutu dan keamanan pangan produk pertanian. Residu pestisida dapat berdampak bagi kesehatan manusia yang mengkonsumsi, sehingga harus diwaspadai (Winarno, 1987; Djojosumarto, 2008 ; Nugrohati dan Untung, 1986). Antisipasi dan penanggulangan residu pestisida pada biji kering kedelai diperlukan untuk menghasilkan tanaman kedelai yang berkualitas, bermutu tinggi dan bebas dari bahan pencemar residu pestisida.

Menteri Kesehatan dan Menteri Pertanian telah mengeluarkan Surat Keputusan Bersama tentang batas maksimum residu pestisida pada hasil pertanian, termasuk di dalamnya adalah produk pertanian biji kering kedelai. Keputusan bersama ini dibuat untuk mencegah dan melindungi masyarakat dari kemungkinan bahaya yang ditimbulkan oleh residu pestisida dalam hasil pertanian. Surat keputusan bersama yang dikeluarkan bernomor 881/MENKES/SKB/VIII/1996.

711/Kpts/TP.270/8/1996

Badan Standardisasi Nasional (BSN) menerbitkan SNI 7313 : 2008 yang berisi tentang batas maksimum beberapa bahan aktif residu pestisida dalam produk pertanian. Perumusan Standar Nasional Indonesia (SNI) ini disusun untuk keamanan pangan, harmonisasi standar dan kelancaran perdagangan baik nasional maupun internasional. Standar telah melalui proses jajak pendapat pada tanggal 21 Juni 2007 sampai dengan 21 September 2007 (Badan Standardisasi Nasional, 2008). Dalam SNI 7313 : 2008, tercantum batas maksium beberapa bahan aktif residu pestisida pada biji kering kedelai (Tabel 2) 
Tabel 2.Batas maksimum residu pestisida pada biji kering kedelai menurut SNI 7313:2008

\begin{tabular}{lclc} 
Bahan aktif pestisida & $\begin{array}{c}\text { Batas } \\
\text { maksimum } \\
\text { residu }(\mathrm{mg} / \mathrm{kg})\end{array}$ & Bahan aktif pestisida & $\begin{array}{c}\text { Batas } \\
\text { maksimum } \\
\text { residu }(\mathrm{mg} / \mathrm{kg})\end{array}$ \\
\hline Aldikarb * & 0,02 & Karbendazim * & 0,2 \\
Amonium Glufosinat & 2 & Karbofuran * & 0,2 \\
Asefat * & 0,5 & Klethodim & 0,5 \\
Benomil * & 0,2 & Klorpirifos & 0,1 \\
Bentazone & 0,05 & Malation & 1 \\
Clethodim & 10 & Metalaksil * & 0,05 \\
2,4 D & 0,01 & Metamidofos * & 0,05 \\
Diflubenzuron * & 0,1 & Metil Azinfos & 0,05 \\
Diklorfos * & 2 & Metomil * & 0,1 \\
Dikuat & 0,2 & Monokrotofos * & 0,05 \\
Disulfoton * & 0,1 & Oksamil & 0,1 \\
Endosulfan & 1 & Parakuat & 0,1 \\
Etiofenkarb $*$ & 0,2 & Paration & 0,05 \\
Etoprofos * & $0,02\left(0,2^{*}\right)$ & Permetrin & 2 \\
Etrimfos * & 0,01 & Porat & 0,05 \\
Fenamifos * & 0,05 & Profenofos & 0,05 \\
Fenitrotion * & 0,1 & Quintozin & 0,01 \\
Fenvalerat * & 0,1 & Sianofenfos & 0,5 \\
Fludioksonil & 0,01 & Sipermetrin & 0,05 \\
Glifosat * & $20(5 *)$ & Spinozad & 0,01 \\
Heptaklor * & 0,02 & Triklorfon & 0,1 \\
Imidakloprid & 2 & Terbufos & 0,05 \\
Karbaril * & $0,2(1 *)$ & Tiodikarb & 0,2 \\
& & Triazofos & 0,05 \\
\hline
\end{tabular}

* Tercantum dalam Keputusan bersama Menkes dan Mentan tahun 1996.

Mengacu pada Surat Keputusan Bersama Menteri Kesehatan dan Menteri Pertanian terdapat beberapa bahan aktif residu pestisida yang tidak tercantum batas maksimumnya tetapi ditemukan pada biji kering kedelai. Berdasarkan pada SNI 7313 : 2008, dalam biji kering kedelai ditemukan bahan aktif malation yang masih di bawah ambang batas. Profenofos ditemukan dalam biji kering kedelai dengan nilai yang sudah berada di atas ambang batas menurut SNI $7313: 2008$.

\section{KESIMPULAN}

Petani kedelai di Kab. Bantul D.I. Yogyakarta, untuk menjaga dan mengamankan produksi kedelai dari serangan organisme pengganggu tanaman, masih mengandalkan pestisida dalam usaha taninya. Pestisida yang biasa digunakan sebagian besar berjenis insektisida. Biaya aplikasi pestisida sebesar $15,9 \%$ dari total biaya produksi dan berpotensi besar dalam mengamankan hasil. Beberapa bahan aktif residu pestisida terdapat pada biji kering kedelai dengan berbagai konsentrasi.

\section{DAFTAR PUSTAKA}

Badan Standardisasi Nasional. 2008. SNI 7313 : 2008 ; Batas maksimum residu pestisida dalam hasil pertanian.

Departemen Kesehatan dan Departemen Pertanian. 1996. Keputusan bersama Menteri Kesehatan dan Menteri Petanian Nomor 881/MENKES/SKB/VIII/1996 1/Kpts/TP.270/8/1996 tentang batas maksimum residu pestisida pada hasil pertanian.

Djojosumarto, P. 2008. Pestisida dan Aplikasinya. PT. Agromedia Pustaka. Jakarta.

Komisi Pestisida Departemen Pertanian. 1997. Metode pengujian residu pestisida dalam hasil pertanian. Departemen Pertanian. Jakarta

Nugrohati, S dan K. Untung. 1986. Pestisida dalam Sayuran. Prosiding Pusat Antar Universitas Pangan dan Gizi. Universitas Gadjah Mada. Yogyakarta 
Shimadzu. 2004. GC Solution : Operation manual. Shimadzu corporation. Kyoto

Winarno, F. G. 1987. Pengaruh pestisida terhadap kesehatan manusia. Simposium
Nasional Pengelolaan Pestisida di Indonesia. $8-10$ Januari 1987. Yogyakarta. 